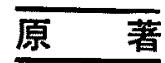

\title{
エラスターゼ（弾性線維分解䤃素）の抗動脈 硬化作用について
}

\author{
京都府立医科大学第一内科学教室 (指導 吉田秀婎教授) \\ 大澤旭

\section{EXPERIMENTAL STUDIES ON THE EFFECT OF ELASTASE ON ATHEROSCLEROSIS}

\begin{abstract}
Akira Osawa
The First Department of Internal Medicine, Kyoto Prefectural University of Medicine

(Director: Professor Hideo Yoshida)
\end{abstract}

\begin{abstract}
概要 19世紀中葉から動脈硬化成立の第一因は血液成分の異常にあるとする説が主導的で, 内膜の異 常も考えられたが，その意義は二次的であるとされた。1935年にDuffがフテローム硬化の成立は 血管壁のなんらかの鹪害が先発する上唱兄てから、この学説の支持者む多く，今日では動脈内膜にmetabolic barrierの存在を仮定するに至り，その損傷をもつて硬化成立の第一因と考えるに至つたが， 損倁因子を酸素欠乏等の外的因子に求めている．この外因性とい5点に疑問を持つ著者は，一つの内 因性物質（膵臟エラスターゼ）に抗動脈硬化作用のあることを示し，その生体内での相対的をたは絶 体的欠乏が, metabolic barrierの機能低下と関連し，傷害血管の発生にあずかると考える。コレス テロール投与中の雄性家鬼に連日エラスターゼ (10mg拉よび $2 \mathrm{mg})$ を笳注投与し， 2 カ月後その家鬼 の血清，大動脈，肝の脂質を抽出し，脂質量，総脂質の脂酸構成，フテロームの形成状況，分画脂質 脂酸構成を観察した：フテロームの形成は阻止され，血清の脂質の降下はなかつたが，動脈壁の総 コレステロール，中性脂肪は減し，橉脂質は增加した，また，脂酸構成は血中においても，組織にお いても改善した，健常家鬼とコレステロール投与家鬼との血清，大動脈および肝の分画脂質脂酸構成 の分析によつて，動脈壁に生理的にmetabolic barrierの存在することを推論し，エラスターゼがこ の機棈の保護にあずかつていると推定した．別に，実験的アテローム硬化家鬼を作製し，その後にエ ラスターゼ(10mg)を連日投与し，フテロームの回復状況を観察したが，その作用は緩徐であつた。
\end{abstract}

\section{I. 緒 言}

Arteriosclerosisは，有史以来人類にみられる疾 患である.1833年にLobsteinが今日用いられるよ りはより広義の意味でここの言葉を用いたが，こ れが近代医学にarteriosclerosisという用語の登場 する端緒となつた。初期に执いても今日と同様

[昭和 44 年11月 29 日受稿]

1967年 (名古屋)，1968年（札幌）の日本老年医 学会総会でこの論文の要旨は発表した。 に，arteriosclerosisへの興味はそのpathogenesis に扣いて大きく展開された.まず，1841年にRokitanskyがその成因として動脈壁の血栓形成を第一 因と唱觉たが，Virchowの反論に耐えず，この学 説は1946年にDuguidが再発見するまで 100 年間 忘却された. Virchow は, 代つて, 内膜浮重説 を唱えたのであるが，これは今世紀初頭に至るま で硬化成立にかんする主導的な学説として斯界に 受け入れられて来たのである. 今日においてる 
Bredtらにより支持されている8 . その主張すると ころは ${ }^{7}$ ，血浆成分が動脈内膜へ侵入し，内膜に 肥厚(Lockerung)を生ぜしめ，内膜にアテローム 硬化病変を形成せしめるとする．1913年に至つて Anitschkowがコレステロール投与家兔が実験的 アテローム硬化を容易に起こすことを発見して から，脂質沈着説が重要な学説となつた．この学 説に和いては，コレステロールの病毒性が主張 され，Learyは，コレステロールが病原性細菌 のように、コッホの条件を満たすことを論じた (1936).

Rokitanskyにおいては無論のこと，Virchow一

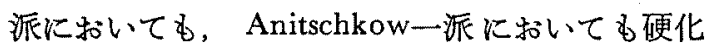
成立の第一因を血液成分，血浆成分または血清脂 質に求めようとする傾向があり，1935年にとの点 にかんして，Duffから反論があり ，血液成分の 異常は硬化成立に重要な因子であることを認め つつも，Duffは第一因を血管壁のなんらかの傷害 (some kind of injury) であると指摘した ${ }^{9)}$.こ の“血管壁の傷害の先発”といら考えの支持者は 多く，そして血管壁の傷害を論ずるに当つて，傷 害を受ける「坐」の存在を考兵る必要が生じ，血 管内膜に，血中脂質の内膜への侵入を制御する metabolic barrier (Zilversmit, 1966) ${ }^{10}$, defence mechanism (Zemplenyi, 1967) ${ }^{11)}$, blood-tissue barrier (Lindner, 1969) ${ }^{12}$ ) 等の存在が仮定され た.この機構を障害する具体的因子として，Zemplenyiは, 動脈壁の酵素学的見地から結論して, それを酸素欠乏にありとしたが，酸素欠乏の原因 は説明せず，さらに硬化栄に拈ける酵素学的変化 と硬化巣との因果関係は不明であるとした．酸素 欠乏によるというこの考光の根底には， barrier の障害因子を外因性と考える思想がみられこのの ことはすでに失敗したコレステロール病毒説とそ の本質が変わらない.

Barrierという機能が存在するならば，必ずこ の機能をになう物質群の存在があるはずであり， barrierの機能の低下は必ずこれら物質群の量的 または質的な変化を意味するであろう。わたくし はbarrierという機能の存在を認め、この機能を
になら物質群として，ムコ多糖体〜ェラスターゼ 系を推定し，エラスターゼの体内における意義を 示すために，エラスターゼ処理家鬼を作製し，そ の動脈壁内の諸变化を脂質代謝の局面から解析し た.

\section{II. 実験対象および実験方法}

\section{（1）実験動物の作製}

実験動物として，体重 2.5〜 3.0kgの白色雄性 家鬼を用い，市販家鬼用固形食(以下>食と略す) を 1 日 1 羽当り $100 \mathrm{~g} て ゙ 10$ 日間飼育し，飼料に慣 らしたのちに，実験を開始した５羽ずつ 6 群を 作り，I 群は值ちに屠殺，I群は上記のフ食に 1.5\%の割合にコレステロールを添加調製した固 形飼料（以下コ食と略す）で 2 力月飼育後屠殺， III群は 2 カ月コ食を与兄，同時に，ブタパンクレ アチンより抽出せるェラスターゼ（弾性線維分解 酵素, 純度 $50 \%$ ）10mg性食水 $1 \mathrm{cc}$ に溶解して, 1 日 1 回連日殿筋に筋注投与したのちに屠殺， IV 群はコ食 2 カ月投与と同時にェラスターゼ $2 \mathrm{mg}$ $1 \mathrm{ml}$ の生食水に溶解して 1 日 1 回連日筋注投与後 屠殺，3 群はコ食 2 カ月投与したのちにフ食で 1 カ月飼育して屠殺，4群はコ食で 2 カ月飼育した のちにフ食で飼育しつつ，エラスターゼを10mg 1 cc の生食水に溶かして 1 日 1 回 1 力月筋注投与後 屠殺（1 群はI 群と，2群はII 群と共通)，I～IV 群は実験前および 2 カ月後に， 3 群，4 群は実験 前， 2 力月後， 3 力月後に，12時間の絶食をさせ のちに，耳静脈から採血，各群の家兔は屠殺後直 ちに開腹, 門脈より生食水淮流を行なつて，肝内 血液をできるだけ排除したのちに，大動脈，肝， 腹壁脂肪組織を取り出し，大動脈は周团組織とと もに外膜を剝離し，各蔵器を科量後 (湿重量), お。 の扮の乳鍊に入れ，ブロア液を少量加えて，大動 脈にはさらに石英砂を加党て，磨哗し脂質の抽出 を行なつた。

（2）脂質の抽出，分離，測定

血液は血清を分離し，可及的速やかに，Dole法 でNEF Aを測定し，総コレステロール（以下C Hと略す)はZurkowski変法で測定 し, 中性脂肪 
Table 1. Lipids and fatty acid composition (prophylactic).

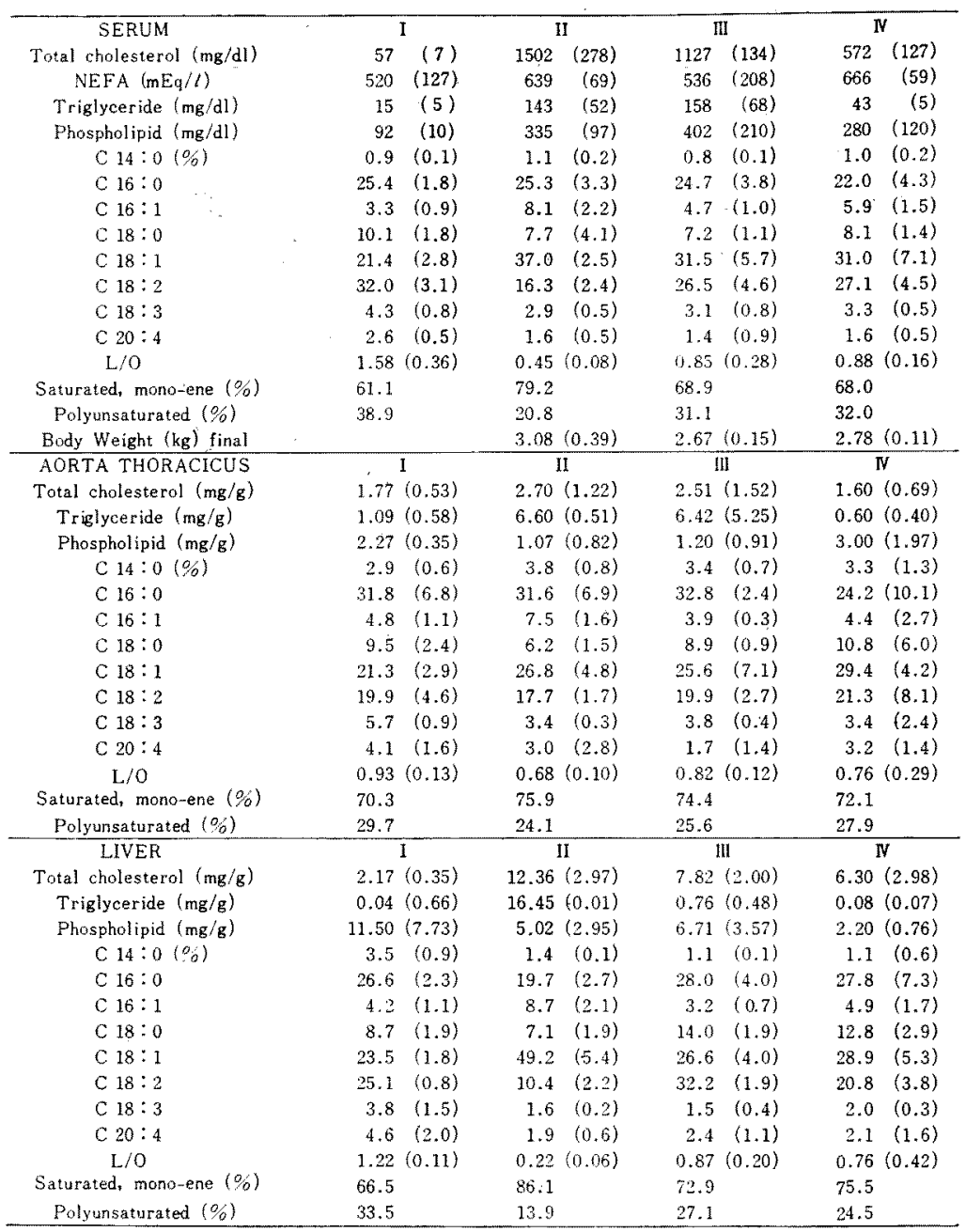

（以下TGと略す）はVan Handel-Zilversmit法 の福井変法で，燐脂質は（以下P L と略す）Fiske-Sabbarow法で測定した。

脂酸構成をみるために，血清 1 ccから脂質を20 倍量のブロア液で 2 回加温抽出を行ない, 最終抽 出を石油エーテルで行なつて, 抽出された脂質を 10\%苛性カリメタノールで跧化し，不錀化物を除 去したのち，2\%硫酸メタノールで脂酸のメチル エステルを作り，ガスクロマト用の試料とした (総脂質脂酸構成).
家鬼の䁍器は前述のように磨砕し, 微細泥状と なつたものを約 $30 \mathrm{ml}$ のブロア液で有栓遠沈管に 移し, 密栓して一晚冷暗所に保存し，その後，血清 の場合之同様に抽出し，抽出液に $0.5 \% \mathrm{NaCl}$ 溶 液を20cc加えて石油エーテル層を分離、残液を石 油エーテルで抽出し，この脂質の石油エーテル液 を一定量とり，CHはZack-Henryの柴田変法で， T Gは福井法で, P L はFiske-Sabbarow法で測 定した.カカスクロマト用の試料は，この脂質溶液 を血清の場合と同様に処理してメチルェステルを 
Table 2. Lipids and fatty acid composition (prophylactic).

\begin{tabular}{|c|c|c|c|c|c|}
\hline AORTA ABDOMINALIS & $i$ & I & II & III & N \\
\hline Total Cholesterol $(\mathrm{mg} / \mathrm{g})$ & 2.75 & $(0.74)$ & $1.85(0.77)$ & $1.84(0.36)$ & $1.60(0.35)$ \\
\hline Triglyceride (mg/g) & 1.14 & $(0.47)$ & $18.99(0.62)$ & $9.62(5.70)$ & $0.75(0.57)$ \\
\hline Phospholipid $(\mathrm{mg} / \mathrm{g})$ & 2.13 & $(0.81)$ & $1.21(0.32)$ & $0.83(0.23)$ & $3.73(3.19)$ \\
\hline C $14: 0(\%)$ & 4.2 & $(1.3)$ & $4.0 \quad(0.4)$ & $3.2 \quad(0.2)$ & $5.5 \quad(1.1)$ \\
\hline C 16:0 & 34.0 & $(4.0)$ & $30.8 \quad(5.1)$ & $33.9 \quad(1.4)$ & $39.2 \quad(6.6)$ \\
\hline C $16: 1$ & 5.3 & $(0.5)$ & $9.8 \quad(2.0)$ & $4.4 \quad(1.0)$ & $6.7 \quad(1.7)$ \\
\hline C $18: 0$ & 8.0 & $(2.2)$ & $5.8 \quad(1.2)$ & $9.5 \quad(1.1)$ & $9.9 \quad(3.2)$ \\
\hline C $18: 1$ & 22.0 & $(2.7)$ & $26.6 \quad(1.7)$ & $24.6 \quad(0.8)$ & $20.8 \quad(3.8)$ \\
\hline C $18: 2$ & 19.7 & $(3.4)$ & $18.1 \quad(2.2)$ & $19.7 \quad(2.5)$ & $14.0 \quad(6.1)$ \\
\hline C $18: 3$ & 5.2 & $(1.1)$ & $3.5 \quad(0.7)$ & $3.2 \quad(1.0)$ & $2.2 \quad(0.9)$ \\
\hline $\mathrm{C} 20: 4$ & 1.6 & $(0.6)$ & $1.4 \quad(1.0)$ & $1.5 \quad(1.6)$ & $1.9 \quad(1.6)$ \\
\hline$L / 0$ & 0.90 & $(0.10)$ & $0.86(0.06)$ & $0.80(0.11)$ & $0.52(0.24)$ \\
\hline DEPOT.FAT & \multicolumn{2}{|c|}{ I } & II & III & v \\
\hline $\mathrm{C} 14: 0(\%)$ & 3.2 & $(0.4)$ & $3.5 \quad(0.5)$ & $4.0 \quad(0.7)$ & $3.7 \quad(0.9)$ \\
\hline C 16:0 & 31.4 & $(2.6)$ & $30.2 \quad(2.3)$ & $31.6 .(2.6)$ & 34.7 \\
\hline C $16: 1$ & 4.0 & $(0.9)$ & $7.9 \quad(1.6)$ & $3.7 \quad(0.5)$ & $(2.1)$ \\
\hline C 18:0 & 7.5 & $(5.2)$ & $6.7 \quad(2.8)$ & $7.4 \quad(0.7)$ & $7.4 \quad(5.2)$ \\
\hline C 18:1 & 21.1 & $(5.2)$ & $26.5 \quad(3.1)$ & $24.7 \quad(0.4)$ & 23.7 \\
\hline$C 18: 2$ & 24.2 & $(1.5)$ & $18.7 \quad(2.5)$ & $24.5 \quad(3.9)$ & 20.2 \\
\hline $\mathrm{C} 18: 3$ & 8.2 & $(2.4)$ & $6.4 \quad(3.2)$ & $4.1 \quad(0.2)$ & $3.4 \quad(1.9)$ \\
\hline C $20: 4$ & 0.3 & $(2.4)$ & trace & trace & $1.0 \quad(0.7)$ \\
\hline $\mathrm{L} / \mathrm{O}$ & 1.16 & $(0.69)$ & $0.71(0.10)$ & $0.99(0.16)$ & $0.91 \quad(0.42)$ \\
\hline
\end{tabular}

作つた。

また，各脂質の分画の脂酸構成をみるために， 血清および藏器の脂質抽出液の一定量をとり，1 群ごとに合わ㜾，珪酸カラムクロマトグラフィ で各分画脂質に分け，その各分画を上記の方法 で，跧化およびェステル化を行なつて，ガスクロ マト用の試料を調製した（分画脂質脂酸構成）。

（3）実験的アテローム硬化の発症の程度の表 現法

実験的アテローム硬化の発症の程度の数量的表 現法として，全大動脈内面積に対するアテローム の面積百分率を算出し，これから表３のように6 度に分けて客観的表現を試みた。

\section{II. 実験成精}

（1）実験的强状硬化家鬼に扣ける脂質代謝招 よびアテローム形成度（表 1 ，表 $2 ，$ 表 3 ) 健常家鬼と実験的アテローム硬化家鬼との血清 および蔵器の脂質量および総脂質脂酸構成を表 1，表 2 のI群および【群の項にそれぞれ示す 脂質の量的変化は，血清では C H, T G, P L
Table 3. Atheroma-Formation.

\begin{tabular}{|c|c|c|c|c|}
\hline Group & No. of Rabbit & (Grade of Atheroma) & Grade & $\begin{array}{c}\text { Portion } \\
\text { of Atheroma }\end{array}$ \\
\hline 1 & $\mathrm{C}_{s}(0) \mathrm{C}_{r}(0)$ & $c,(0) c,(0) c_{18}(0)$ & 0 & \\
\hline II & $C_{1}(c) C_{2}(0)$ & $C_{3}(e) C_{1}(e) C_{:}(d)$ & a & -2.4 \\
\hline III & $E_{\uparrow}(b) E_{*}(b)$ & $E_{9}(b) E_{13}(0)$ & b & $2.5-4.9$ \\
\hline N & $E_{1}(0) E_{z}(0)$ & $E,(a) E,(a) E,(a)$ & c & $5.0 \sim 9.9$ \\
\hline 3 & $E_{n}(c) E_{m}(a)$ & $E_{\text {is }}(d) E_{i s}(c)$ & $d$ & $10.0 \sim 19.9$ \\
\hline 4 & $E_{m}(c) E_{m}(b)$ & $E_{n}(0) E_{u}(e) E_{i}(d)$ & e & $20.0-$ \\
\hline
\end{tabular}

は硬化家鬼には著しく増加し，NEF A 軽度に 増加する，大動脈では，P Lは減じている，肝で も $\mathrm{CH}$ ，T Gが増加し，P Lが減じている.

総脂質脂酸構成は，健常家鬼に比べて，硬化家 兔では，血清でパルミトオレイン酸 $\left(\mathrm{C}_{16: 1}\right)$, オレ イン酸 $\left(\mathrm{C}_{18: 1}\right)$ の百分比の増加が著しく, リノー ル酸 $\left(\mathrm{C}_{18: 2}\right)$, リノレン酸 $\left(\mathrm{C}_{18: 9}\right)$, アラキドン酸 $\left(\mathrm{C}_{20: 4}\right)$ が著しく減じ，いずれも推計学的に有意 の差をもつて認められた $(\mathrm{p}<0.05)$. 胸部および 腹部大動脈，および脂肪組織ではほぼ血清のもの に一致する脂酸構成がみられた，肝ではそのほか にパルミチン酸の百分比が減じている。な机（） 
Table 4. Fractioned fatty acid composition (prophylactic).

\begin{tabular}{|c|c|c|c|c|c|c|c|c|c|c|c|c|}
\hline \multirow{2}{*}{$\begin{array}{c}\text { SERUM } \\
\%\end{array}$} & \multirow[b]{2}{*}{ I } & \multicolumn{3}{|c|}{ CE-Fraction } & \multicolumn{4}{|c|}{ TG-Fraction } & \multicolumn{4}{|c|}{ PL-Fraction } \\
\hline & & II & III & N & I & II & III & $\mathbf{N}$ & 1 & II & III & IV \\
\hline C 14:0 & 1.1 & 0.1 & 0.6 & 0.6 & 1.0 & 0.2 & 2.0 & 3.6 & 2.2 & 0.1 & 1.9 & 1.1 \\
\hline$C 16: 0$ & 23.6 & 17.3 & 28.8 & 23.4 & 37.4 & 34.9 & 45.1 & 12.7 & 28.7 & 27.0 & 28.7 & 31.8 \\
\hline $\mathrm{C} 16: 1$ & 3.5 & 10.3 & 3.7 & 6.5 & 4.9 & 10.7 & 3.7 & 7.2 & 5.6 & 3.2 & 3.1 & 2.6 \\
\hline C 18:0 & 4.5 & 4.1 & 7.6 & 5.6 & 6.0 & 3.5 & 4.8 & 6.4 & 23.1 & 16.5 & 20.6 & 14.5 \\
\hline C 18: 1 & 20.2 & .50 .5 & 31.8 & 39.3 & 21.9 & 31.7 & 21.6 & 37.3 & 15.4 & 18.2 & 13.8 & 16.5 \\
\hline C 18:2 & 40.1 & 13.8 & 23.0 & 18.9 & 22.8 & 15.5 & 20.8 & 28.1 & 20.0 & 29.7 & 25.8 & 26.9 \\
\hline$C 18: 3$ & 4.5 & 3.1 & 3.9 & 4.6 & 4.6 & 2.9 & 2.0 & 3.9 & 1.5 & 1.5 & 1.6 & 2.6 \\
\hline$C 20: 4$ & 2.5 & 0.8 & 0.6 & 1.1 & 1.4 & 0.6 & tr. & 0.8 & 3.5 & 3.8 & 4.5 & 4.0 \\
\hline$S-F A$ & 52.9 & 82.3 & 72.5 & 75.4 & 71.2 & 81.0 & 77.2 & 67.2 & 75.0 & 65.0 & 68.1 & 66.5 \\
\hline$P-F A$ & 47.1 & 17.7 & 27.5 & 24.6 & 28.8 & 19.0 & 22.8 & 32.8 & 25.0 & 35.0 & 31.9 & 33.5 \\
\hline$L / 0$ & 1.84 & 0.27 & 0.72 & 0.48 & 1.23 & 0.49 & 0.96 & 0.75 & 1.32 & 1.36 & 1.87 & 1.57 \\
\hline AORTA & \multicolumn{4}{|c|}{ CE-Fraction } & \multicolumn{4}{|c|}{ TG-Fraction } & \multicolumn{4}{|c|}{ PL-Fraction } \\
\hline THOR. $\%$ & I & II & III & $\mathbf{N}$ & 1 & 11 & III & N & 1 & II & III & $\mathbb{N}$ \\
\hline C 14:0 & 4.0 & 2.3 & 1.9 & - & 3.0 & 4.5 & 4.4 & 4.8 & 2.4 & 4.7 & 3.7 & 8.5 \\
\hline C 16:0 & 27.0 & 21.1 & 25.5 & - & 33.2 & 31.8 & 37.3 & 55.1 & 33.1 & 30.0 & 38.5 & 56.6 \\
\hline C 16: 1 & 6.7 & 7.9 & 5.5 & - & 4.1 & 9.0 & 4.5 & 4.2 & 5.7 & 5.6 & 4.4 & 3.7 \\
\hline C 18:0 & 10.6 & 5.5 & 6.9 & - & 6.5 & 5.9 & 8.0 & 9.5 & 16.4 & 16.4 & 20.6 & 19.9 \\
\hline C $18: 1$ & 24.2 & 50.5 & 35.4 & - & 21.0 & 24.4 & 22.8 & 18.1 & 26.6 & 22.2 & 15.3 & 4.1 \\
\hline C 18:2 & 21.3 & 10.1 & 21.8 & .- & 24.8 & 19.0 & 19.1 & 6.7 & 10.0 & 12.6 & 7.0 & 2.4 \\
\hline C 18: 3 & 3.6 & 2.9 & 2.8 & - & 7.0 & 4.9 & 3.9 & 1.5 & 1.2 & 2.2 & tr. & 2.2 \\
\hline$C 20: 4$ & 2.6 & 0.2 & 0.2 & - & 0.4 & 0.5 & tr. & 0.1 & 4.6 & 6.3 & 10.5 & 2.6 \\
\hline$S-F A$ & 72.5 & 86.8 & 75.2 & 73.4 & 67.8 & 75.6 & 77.1 & 91.7 & 84.2 & 78.9 & 82.5 & 92.8 \\
\hline$P-F A$ & 27.5 & 13.2 & 24.8 & 26.6 & 32.2 & 24.4 & 23.0 & 8.3 & 15.8 & 21.1 & 17.5 & 7.2 \\
\hline $\mathrm{L} / \mathrm{O}$ & 0.88 & 0.20 & 0.62 . & - & 1.30 & 0.78 & 0.84 & 0.38 & 0.80 & 0.57 & 0.46 & 0.57 \\
\hline LIVER & \multicolumn{4}{|c|}{$C E-F$ raction } & \multicolumn{4}{|c|}{ TG-Fraction } & \multicolumn{4}{|c|}{ PL-Fraction } \\
\hline$\%$ & I & II & III & $\mathrm{N}$ & I & II & III & $\mathrm{N}$ & I & II & m & N \\
\hline $\mathrm{C} 14: 0$ & 4.7 & 1.4 & 0.9 & 1.3 & 3.2 & 3.6 & 2.5 & 3.3 & 0.4 & 3.0 & 1.7 & 3.6 \\
\hline$c 16: 0$ & 19.8 & 16.7 & 28.7 & 36.4 & 40.6 & 27.8 & 50.9 & 56.9 & 23.8 & 25.1 & 26.5 & 32.6 \\
\hline$C 16: 1$ & 4.6 & 11.6 & 4.2 & 16.2 & 4.8 & 10.0 & 3,3 & 4.4 & 1.6 & 4.8 & 2.2 & 4.3 \\
\hline C 18:0 & 6.0 & 4.7 & 8.4 & 8.8 & 8.4 & 10.5 & 8.6 & 6.8 & 21.4 & 20.3 & 28.2 & 19.0 \\
\hline C $18: 1$ & 43.2 & 54.4 & 40.9 & 18.5 & 23.9 & 35.8 & 20.1 & 19.4 & 14.0 & 21.1 & 12.5 & 12.3 \\
\hline C $18: 2$ & 6.0 & 8.4 & 14.0 & 15.3 & 15.4 & 8.0 & 10.9 & 7.4 & 29.0 & 18.3 & 25.7 & 27.4 \\
\hline$C 18: 3$ & 0.7 & 2.5 & 2.2 & 3.1 & 1.5 & 1.9 & 2.3 & 1.6 & 1.3 & 2.1 & 1.0 & 0.3 \\
\hline$C 20: 4$ & 15.0 & 0.3 & 0.7 & 0.4 & 2.2 & 2.4 & 1.4 & 0.2 & 8.5 & 5.3 & 2.2 & 0.5 \\
\hline$S-F A$ & 78.3 & 88.8 & 83.1 & 81.2 & 80.9 & 87.7 & 85.4 & 90.8 & 61.8 & 74.3 & 71.1 & 71.0 \\
\hline$P-F A$ & 21.7 & 11.2 & 16.9 & 18.8 & 19.1 & 12.3 & 14.6 & 9.2 & 38.2 & 25.7 & 28.9 & 28.2 \\
\hline $\mathrm{L} / 0$ & 0.14 & 0.15 & 0.34 & 0.83 & 0.64 & 0.31 & 0.54 & 0.32 & 2.07 & 0.87 & 2.06 & 2.22 \\
\hline
\end{tabular}

内は標準偏差を示す

アテロームの形成状沉は表 3 のよらにI群では 全く認めないが，II 群では高度の形成をみた。

（2）エラスターゼ投与によるアテローム硬化 阻止実験（表 1 ，表 2 ，表 3 ）

コレステロール投与と同時にェラスターゼを投 与した家鬼群の血清おょび臓器の脂質および総脂 質脂酸構成を表 1 ，表 2 の II 群（エラスターゼ10 mg) とIV群 (エラスターゼ $2 \mathrm{mg}$ ) の項に示す

脂質の変化は血清，大動脈，肝のいずれにおい てむ，III群およびI群は，I群 (正常群) と II 群 (ニレステロール投与群) との中間の值を示して
いる．ただ血清では，四群，IV群の值はI群より

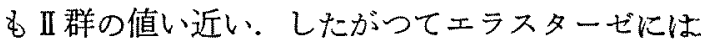
血清脂質降下力は弱いとい方る．総脂質脂酸構成 の变化は，L/O比に端的に表現されているよう

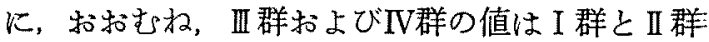
の中間の值を示す さらに大動脈のアテロームの 形成は，表 3 に示寸ように，II 群よりは軽く，I 群より強い。すなわち，エラスターゼによりアテ ロームの形成が阻止されている.

（3）些験的アテローム硬化家鬼における分画 脂質脂酸構成(表 4，表 1 ；表 5 ，表 6 ，図A) 表 4 は実験的アテローム硬化家兔の血清，胸部 
Table 5. Saturated, mono-ene and polyunsaturated in fatty acid composition (prophylactic).

\begin{tabular}{|c|c|c|c|c|c|c|c|c|c|}
\hline & & Satur & ed and & nono-e & (s) & & lyunsat & ated ( & \\
\hline & $\mathrm{fr}$. & I & II & III & $\mathrm{N}$ & I & II & III. & $\vec{N}$ \\
\hline \multirow{4}{*}{ 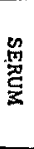 } & TF & $\%_{61.1}$ & 79.2 & 68.9 & 68.0 & $\%_{38.9}$ & 20.8 & 31.1 & 32.0 \\
\hline & $C E$ & $\mathbf{5 2 . 9}$ & 82.3 & 72.5 & 75.4 & 47.1 & 17.7 & 27.5 & 24.6 \\
\hline & TC & 71.2 & 81.0 & 77.2 & 67.2 & 28.8 & 19.0 & 22.8 & 32.8 \\
\hline & PL & 75.0 & 65.0 & 68.1 & 66.5 & 25.0 & 35.0 & 31.9 & 33.5 \\
\hline \multirow{4}{*}{ 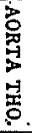 } & TF & 70.3 & 75.9 & 74.4 & 72.1 & 29.7 & 24.1 & 25.8 & 27.9 \\
\hline & $\mathrm{CE}$ & 22.5 & 86.8 & 75.2 & 73.4 & 27.5 & 13.2 & 24.8 & 26.6 \\
\hline & TG & 67.8 & 75.6 & $\dot{\eta} \eta .1$ & 91.7 & 32,2 & 24.4 & 23.0 & 8.3 \\
\hline & $\mathrm{PL}$ & 84.2 & 78.9 & 82.5 & 92.7 & 15.8 & 21.1 & 17.5 & 7.2 \\
\hline \multirow{4}{*}{ 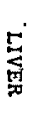 } & $T F$ & 66.5 & 86.1 & 72.9 & 75.5 & 33.5 & 13.9 & 27.1 & 24.5 \\
\hline & CE & 78.3 & 88.8 & 83.1 & 81.2 & 21.7 & 11.2 & 16.9 & 18.8 \\
\hline & TG & 80.9 & 87.7 & 85.4 & 90.8 & 19.1 & 12.3 & 14.6 & 9.2 \\
\hline & PL & 61.8 & 74.3 & 71.1 & 71.8 & 38.2 & 25.7 & 28.9 & 28.2 \\
\hline
\end{tabular}

大動脈，肝のコレステロールエステル（以下C E と略す）分画，TG分画，P L 分画についての分 画脂質脂酸構成である．分析の対象とした代表的 脂酸 8 種のうち, 体内合成可能の脂酸(飽和和よび monoene) をS 脂酸と呼び，多価不飽和脂酸を P脂酸と乎ぶことにする，前者に属するるのは， ミリスチン酸 $\left(\mathrm{C}_{14: 0}\right)$, パルミチン酸 $\left(\mathrm{C}_{16: 0}\right)$, パ ルミトオレイン酸，ステアリン酸 $\left(\mathrm{C}_{18: 0}\right)$,オレイ ン酸の 5 種であり，後者に属するるのは、リノー ル酸, リノレン酸, アラキドン酸の 3 種である.

表 1 扎よび表 4 から， $\mathrm{S}$ 脂酸括よび $\mathrm{P}$ 脂酸の項 の数値を取り出して整理すると表 5 のようにな る.この表 5 において，各脂質分画ごとに，I 群 を基準とした II 群，回群，IV群の増減を $\mathrm{S}$ 脂酸に ついては $\Delta \mathrm{S} ， \mathrm{P}$ 脂酸については $\Delta \mathrm{P}$ とて整理
Table 6. Deviation of fatty acid composition from normal.

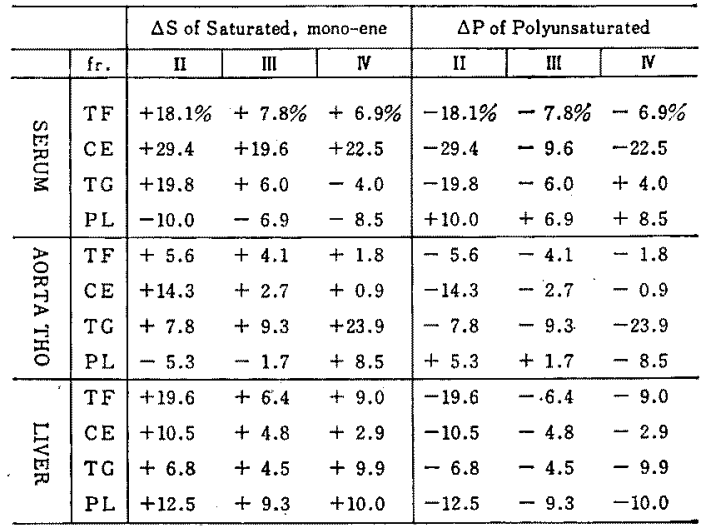

すると表 6 のようになる。

表 6 に打いてまず，硬化家鬼群 (II群) の $\Delta \mathrm{P}$ （または $\Delta \mathrm{S}$ ）の数値に注目すると缄器ごとの四 つの $\Delta \mathrm{P}$ (または $\Delta \mathrm{S}$ ）の值に興味ある組合せを みる、すなわち，血清では，総脂質脂酸構成 ( $\mathrm{T}$ F) $の \Delta \mathrm{P}=-18.9 \%, \mathrm{C} \mathrm{E} \circlearrowleft \Delta \mathrm{P}=-29.4 \%$, $\mathrm{T} \mathrm{G} \Delta \Delta \mathrm{P}=-19.8 \%, \quad \mathrm{P} L の \Delta \mathrm{P}=+10.0 \%$ と なつており，胸部大動脈では， T F の $\mathrm{P}=$ $5.6 \%, \mathrm{C} \mathrm{E} \Delta \mathrm{P}=-14.3 \%, \quad \mathrm{~T} \mathrm{G} \Delta \mathrm{P}=-$ $7.8 \%, \mathrm{P}$ Lの $\mathrm{P}=+5.3 \%$ であ, 肝では $\mathrm{T}$ $\mathrm{F} の \Delta \mathrm{P}=-19.6 \%, \mathrm{C} \mathrm{E} \Delta \mathrm{P}=-10.5 \%, \mathrm{~T} \mathrm{G}$ の $\Delta \mathrm{P}=-6.8 \%, \quad \mathrm{P} \mathrm{L} \Delta \mathrm{P}=-12.5 \%$ となつ ている、 $\Delta \mathrm{S}$ はいずれる対応する $\Delta \mathrm{P}$ と絶体值が 等しく符号が反対である.ここで気付くことは， 血清と大動脈とでは， T F， C E， T G， P L の

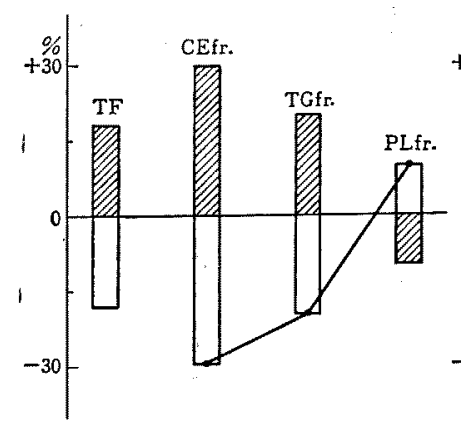

Fig. $A_{1}$. Serum.

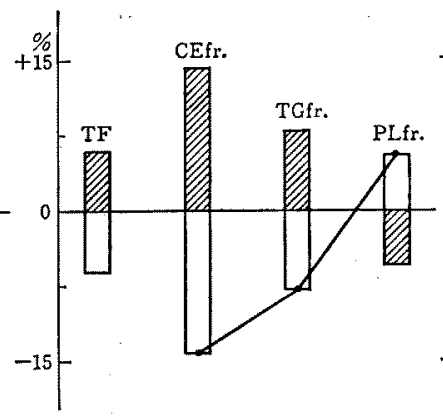

Fig. $A_{2}$. Aorta thoracicus.

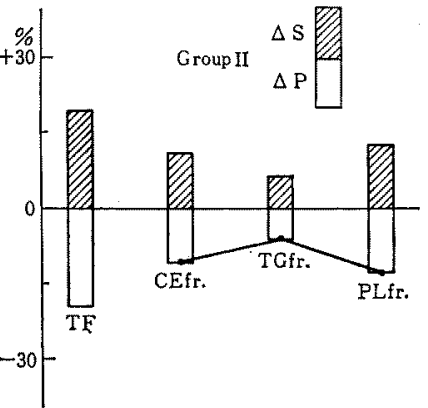

Fig. Aq. Liver. 


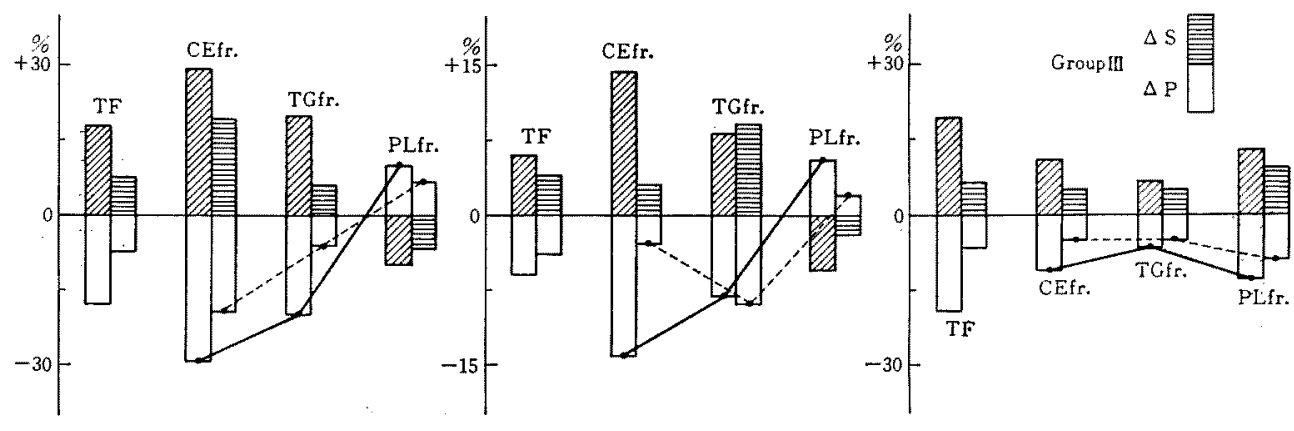

Fig. $\mathbf{B}_{1}$. Serum.

Fig. $B_{2}$. Aorta thoracicus.

Fig. $B_{3}$. Liver.

$\Delta \mathrm{P}$ (または $\Delta \mathrm{S}$ ）の符号の組合せが等しく，肝 では異なつているという特徵である。この関俰を 図示したものが，II群については，図Aであり，

群については図 Bであつて，硬化成立に伴う各
脂質分画の $\Delta \mathrm{S}$ 执よび $\Delta \mathrm{P}$ の変化の方向が血清と 大動脈と一致し，肝で異なつていることが明瞭と なるＩV群については図示しなかつた。

（4）エラスタービ投与による阻止実験の分画

Table 7. Lipids and fatty acid composition (recovery).

\begin{tabular}{|c|c|c|c|c|c|c|c|c|}
\hline SERUM & \multicolumn{2}{|c|}{1} & \multicolumn{2}{|c|}{2} & \multicolumn{2}{|c|}{3} & \multicolumn{2}{|c|}{4} \\
\hline Total cholesterol (mg/dl) & 57 & (7) & 1502 & $(278)$ & 406 & $(135)$ & 222 & (78) \\
\hline Triglyceride (mg/dl) & 15 & (5) & 143 & (52) & 74 & (41) & 61 & (30) \\
\hline Phospholipid (mg/dl) & 92 & (10) & 335 & $(97)$ & 251 & (65) & 119 & $(50)$ \\
\hline C $14: 0\left(0_{0}\right)$ & 0.9 & $(0.1)$ & 1.1 & $(0.2)$ & 0.7 & $(0.2)$ & 1.0 & $(0.1)$ \\
\hline$C 16: 0$ & 25.4 & $(1.8)$ & 25.3 & $(3.3)$ & 20.7 & $(1,3)$ & 28.6 & $(1.1)$ \\
\hline$C 16: 1$ & 3.3 & $(0.9)$ & 8.1 & $(2.2)$ & 8.8 & $(1.0)$ & 3.6 & 12.4 \\
\hline $\mathrm{C} 18: 0$ & 10.1 & $(1.8)$ & 7.7 & $(4.1)$ & 5.8 & $(1.8)$ & 9.2 & $(1.3)$ \\
\hline C $18: 1$ & 21.4 & $(2.8)$ & 37.0 & $(2.5)$ & 37.0 & $(6.0)$ & 22.8 & $(5.0)$ \\
\hline C $18: 2$ & 32.0 & $(3.1)$ & 16.3 & $(2.4)$ & 21.5 & $(3.2)$ & 27.2 & $(5.0)$ \\
\hline C $18: 3$ & 4.3 & $(0.8)$ & 2.9 & $(0.5)$ & 3.4 & $(1.1)$ & 4.2 & $(1.3)$ \\
\hline C $20: 4$ & 2.6 & $(0.5)$ & 1.6 & $(0.5)$ & 2.1 & $(2.0)$ & 3.8 & $(2.0)$ \\
\hline $\mathrm{L} / \mathrm{O}$ & 1.58 & $(0.36)$ & 0.45 & $(0.08)$ & 0.57 & $(0.51)$ & 1.28 & $(0.54)$ \\
\hline Body Weight $(\mathrm{kg})$ final & & & 3.08 & $(0.39)$ & 3.39 & $(0.22)$ & 2.94 & $(0.62)$ \\
\hline AORTA THORACICUS & 1 & & & 2 & 3 & 3 & 4 & 4 \\
\hline Total cholesterol (mg/g) & 1.77 & $(0.53)$ & 2.70 & $(1.22)$ & 2.95 & $(2.37)$ & 4.14 & $(4.13)$ \\
\hline Triglyceride $(\mathrm{mg} / \mathrm{g})$ & 1.09 & $(0.58)$ & 6.60 & $(0.51)$ & 15.50( & $12.33)$ & 13.55( & $14.56)$ \\
\hline Phospholipid (mg/g) & 2.27 & $(0.35)$ & 1.70 & $(0.82)$ & 0.90 & $(0.15)$ & 0.89 & $(0.37)$ \\
\hline C $14: 0(\%)$ & 2.9 & $(0.6)$ & 3.8 & $(0.8)$ & 3.0 & $(0.4)$ & 4.3 & $(1.0)$ \\
\hline C $16: 0$ & 31.8 & $(6.8)$ & 31.6 & $(6.9)$ & 31.4 & $(4.4)$ & 28.5 & $(2.3)$ \\
\hline$C 16: 1$ & 4.8 & $(1.1)$ & 7.5 & $(1.6)$ & 6.0 & $(0.8)$ & 6.7 & $(0.7)$ \\
\hline C 18:0 & 9.5 & $(2.4)$ & 6.2 & $(1.5)$ & 7.0 & $(0.8)$ & 8.0 & (1.6) \\
\hline C $18: 1$ & 21.3 & $(2.9)$ & 26.8 & $(4.8)$ & 25.3 & $(4.6)$ & 27.2 & $(4.1)$ \\
\hline C $18: 2$ & 19.9 & $(4.6)$ & 17.7 & $(1.7)$ & 20.4 & $(3.5)$ & 19.3 & $(3.0)$ \\
\hline C $18: 3$ & 5.7 & $(0.9)$ & 3.4 & $(0.3)$ & 4.4 & $(0.4)$ & 4.7 & $(2.3)$ \\
\hline C $20: 4$ & 4.1 & (1.6) & 3.0 & $(2.8)$ & 2.5 & $(1.2)$ & 1.3 & $(1.3)$ \\
\hline$L / 0$ & 0.93 & $(0.13)$ & 0.68 & $(0.10)$ & 0.79 & $(0.19)$ & 0.70 & $(0.15)$ \\
\hline LIVER & 1 & 1 & & 3 & 3 & 3 & 4 & 4 \\
\hline Total cholesterol $(\mathrm{mg} / \mathrm{g})$ & 2.17 & $(0.35)$ & 12.36 & $(2.27)$ & 9.18 & $(7.45)$ & 4.20 & $(1.82)$ \\
\hline Triglyceride $(\mathrm{mg} / \mathrm{g})$ & 0.04 & $(0.06)$ & 16.45 & $(0.01)$ & 0.88 & $(0.25)$ & 0.86 & $(0.24)$ \\
\hline Phospholipid $(\mathrm{mg} / \mathrm{g})$ & 11.50 & $(7.73)$ & 5.02 & $(2.95)$ & 7.96 & $(2.34)$ & 7.58 & $(2,58)$ \\
\hline C $14: 0(\%)$ & 3.5 & $(0.9)$ & 1.4 & $(0.1)$ & 0.8 & $(0.3)$ & 0.8 & $(0.2)$ \\
\hline C 16:0 & 26.6 & $(2.3)$ & 19.7 & $(2.7)$ & 26.5 & $(4.2)$ & 27.4 & $(2.3)$ \\
\hline $\mathrm{C} 16: 1$ & 4.2 & $(1,1)$ & 8.7 & (2.1) & 5.3 & $(3.8)$ & 2.5 & $(1.0)$ \\
\hline C $18: 0$ & 8.7 & (1.9) & 7.1 & $(1.9)$ & 10.3 & $(3.8)$ & 20.7 & (1.9) \\
\hline C $18: 1$ & 23.5 & (1.8) & 49.2 & $(5.4)$ & 29.4 & $(12.0)$ & 16.8 & $(2.8)$ \\
\hline C $18: 2$ & 25.1 & $(0.8)$ & 10.4 & $(2.2)$ & 21.6 & $(7.5)$ & 25.6 & $(1.1)$ \\
\hline C 18:3 & 3.8 & (1.5) & 1.6 & $(0.2)$ & 3.0 & $(0.6)$ & 1.9 & $(1.0)$ \\
\hline C $20: 4$ & 4.6 & $(2.0)$ & 1.9 & $(0.6)$ & 3.1 & $(1.9)$ & 4.3 & $(0.9)$ \\
\hline $\mathrm{L} / \mathrm{O}$ & 1.22 & $(0,11)$ & 0.22 & $(0.06)$ & 0.98 & $(0.70)$ & 1.58 & $(0.33)$ \\
\hline
\end{tabular}


Table 8. Lipids and fatty acid composition (recovery).

\begin{tabular}{|c|c|c|c|c|}
\hline AORTA ABDOMINALIS & 1 & 2 & 3 & 4 \\
\hline Total cholesterol (mg/g) & $2.75(0.74)$ & $1.85(0.77)$ & $2.68(0.45)$ & $1.27(0.56)$ \\
\hline Triglyceride $(\mathrm{mg} / \mathrm{g})$ & $1.14(0.47)$ & $18.99(0.62)$ & $35.43(19.9)$ & $11.48(4.97)$ \\
\hline Phospholipid (mg/g) & $2.13(0.81)$ & $1.21(0.32)$ & $1.32(0.45)$ & $1.14(0.38)$ \\
\hline C $14: 0(\%)$ & $4.2 \quad(1.3)$ & $4.0 \quad(0.4)$ & $3.4(0.3)$ & $4.8 \quad(0.5)$ \\
\hline C $16: 0$ & $34.0 \quad(4.0)$ & $30.8 \quad(5.1)$ & $32.1 \quad(1.5)$ & $34.0 \quad(1.7)$ \\
\hline $\mathrm{C} 16: 1$ & $5.3(0.5)$ & $9.8 \quad(2.1)$ & $8.2(1.8)$ & $7.6(1.1)$ \\
\hline C $18: 0$ & $8.0 \quad(2.2)$ & $5.8 \quad(1.2)$ & $5.8(0.6)$ & $6.9(0.8)$ \\
\hline $\mathrm{C} 18: 1$ & $22.0 \quad(2.7)$ & $26.6(1.7)$ & $22.6 \quad(1.7)$ & $24.6 \quad(2.7)$ \\
\hline C $18: 2$ & $19.7 \quad(3.4)$ & $18.1 \quad(2.2)$ & $21.2(1.9)$ & $17.2(2.1)$ \\
\hline C $18: 3$ & $5.2,(1.1)$ & $3.5(0.7)$ & $5.4 \quad(1.0)$ & $3.7(1.9)$ \\
\hline $\mathrm{C} 20: 4$ & $1.6(0.6)$ & $1.4(1.0)$ & $1.3(0.5)$ & $1.1 \quad(0.7)$ \\
\hline $\mathrm{L} / 0$ & $0.90(0.10)$ & $0.86(0.06)$ & $0.95(0.15)$ & $0.70(0.14)$ \\
\hline DEPOT FAT & I & 2 & 3 & 4 \\
\hline C $14: 0(\%)$ & $3.2(0.4)$ & $3.5 \quad(0.5)$ & $3.7 \quad(0.6)$ & $4.3 \quad(0.7)$ \\
\hline C $16: 0$ & $31.4 \quad(2.6)$ & $30.2 \quad(2.3)$ & $29.7 \quad(5.1)$ & $31.1(1.5)$ \\
\hline C $16: 1$ & $4.0 \quad(0.9)$ & $7.9 \quad(1.6)$ & $5.2 \quad(2.0)$ & $4.3(1.3)$ \\
\hline C 18:0 & $7.5 \quad(5.2)$ & $6.7 \quad(2.8)$ & $6.0 \quad(0.3)$ & $6.5 \quad(0.7)$ \\
\hline C $18: 1$ & $21.1 \quad(5.2)$ & $26.5 \quad(3.1)$ & $23.6 \quad(3.0)$ & $24.1 \quad(5.1)$ \\
\hline C $18: 2$ & $24.2 \quad(1.5)$ & $18.7 \quad(2.5)$ & $25.2 \quad(3.8)$ & $22.7 \quad(3.1)$ \\
\hline C $18: 3$. & $8.2(2.4)$ & $6.4 \quad(3.2)$ & $6.6 \quad(5.4)$ & 6.5 (1.6) \\
\hline$C 20: 4$ & $0.3(2.4)$ & trace & trace & $0.5 \quad(1.2)$ \\
\hline $\mathrm{L} / \mathrm{O}$ & $1.16(0.69)$ & $0.71(0.10)$ & $1.10(0.20)$ & $0.97(0.30)$ \\
\hline
\end{tabular}

脂質脂酸構成（表 5 ，表 6 ，図 B )

前項と同様にして，表 6 のII群の項を作り，図 Aにグラフを書き加えると図Bとなる，血清と肝 では，エラスターゼ投与により， $\Delta \mathrm{S} ， \Delta \mathrm{P}$ 絶 体值が和さ兄られるが，变化の方向は前項と同様 の特徵がある。大動脈の $\mathrm{T} \mathrm{G}$ 分画の $\Delta \mathrm{S} ， \Delta \mathrm{P}$ は エラスターゼ投与で絶体值がむしろ增大してい る。

（5）エラスターゼ投与によるアテローム硬化 回復実験（表 7 表 8 )

表 7 と表 8 がこの実験の成績であり，脂質の変 化は 3 群 (対照群) と 4 群（エラスターゼ10mg投 与）を比較して，血清では C H，T G，PLのい ずれも幾分か減少の傾向があり，肝では C H が減 じ，胸部大動脈では変化をみなかつた。

総脂質脂酸構成は，血清では $\mathrm{C}_{16: 0}$ と $\mathrm{C}_{18: 0}$ の百分 比が増し, $\mathrm{C}_{16: 1}, \mathrm{C}_{18: 1}$ の百分比が減じ, $\mathrm{C}_{18: 2}, \mathrm{C}_{18: 8}$, $\mathrm{C}_{20: 4}$ の百分比が増す 肝でる同様の傾向がみら れるが，大動脈と脂肪組織では著変をみとめな い.すなわち，既成の実験的アテローム硬化巣に 対するエラスターゼの作用は， 1 カ月の投与で は，血清と肝の脂質へは影響を与克るが，大動脈 には余り及んでいない，アテロームの形成状沉は 表 3 に示すと扣り，回復は著しくない。

\section{IV. 考 案}

1）エラスターゼの抗動脈硬化作用について Anitschkowの 実験 ${ }^{1)}$ 以来, 家鬼にコレステロ 一ルを投与すると，大動脈にヒトのアテローム硬 化に似た血管病変の起こることが，多くの研究 者帛によつて確かめられている. 著者もコレステ ロール投与に上り家兔に血清脂質叔よび脂酸構成 の異常, あるいはアテロームの形成等, 動脈硬化 症患者 ${ }^{2}$ のそれと類似の状態を作りえた。そして コレステロールと同時に膵蔵性のエラスターゼ (弾性線維分解醉素) を投与すると, この家鬼大 動脈の血管病変の進展が軽度にとどまり，血清お よび大動脈の脂質量, 脂酸構成もより健常に保た れるといら抗硬化作用を認めた。 蛋白同化ステロ イド、リノール酸エチルェステル，デキストラン 硫酸 (3) $^{2} \mathrm{VB}_{2}$ 酪酸エステル，その他についても同 様の抗硬化作用のあることが発表されているが， 生理的に体内に存在しない物質か，または壁代謝 に関与が明らかでない物質である。それに反し て，ここに示したエラスターゼは生理的に体内で 産生される内因性物質であり，後述するように， 大動脈の壁代謝に関連する物質である.

エラスターゼは1904年にEijkmankよつてpseudomonas pyocyaneak発見され，1949年にBaló 
およびBangaによつてウシの脺缄から発見され だ).エラスターゼは膵臓の $\alpha$ 細胞より生成され ると考えられるホルモン様の物質で では特異的にニラスチンを分解する゙う エラスタ 一ゼはエラスチンの分解ばかりでなく，合成にる 決定的意義があり，かつ，ェラスターゼは無傷の エラスチンの維持にさらに重要であることが指摘 された．エラスターゼは成分的には単一でなく， elastomucase $\left(E_{1}\right)$ とelastoproteinase $\left(E_{2}\right)$ との 2

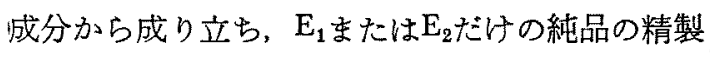
は困難とされる． $\mathrm{E}_{2}$ はェラスチンの分解に特異的 であるが， $E_{1}$ 酸性ムコ多糖体（以下AMP S と 略す）に関係するといわれの，その作用点が種々 仁論義されている.

2）既成のアテローム病変に対するェラスター ゼの作用について

既成のアテロームに対しては，エラスターゼの 1 カ月の投与では，アテロームの回復は著しくな い（表 7, 表 8).これはエラスターゼが新たな脂 質沈着は防ぎ得ても，脂質の内膜からの除去には 直接の能力をもた炈めであるう.

3）動脈壁における metabolic barrierの存在に ついて

表 1 に扣いて，血清と大動脈と肝との脂酸構成 淁健常の家鬼群 ( I 群) の場合について比較して みると，かなりよく互いに類似しているが全く同 一でない。この健常家鬼にコレステロールを投与 すると，表１のII群の項の脂酸構成を示すように なるのであるが，I 群から II 群への脂酸の変動の 様相を，表 1 の総脂質脂酸構成のみならず，表 4 の分画脂質脂酸構成子考慮して作製したのが，表 5 ，表6であり，表6の図表化したものが図A

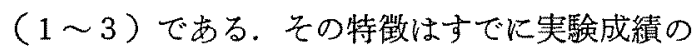
項の（3）で説明した，その要点は，コレステロー ル投与時, 図A中の折線が端的に明示するよう に，脂酸の動きが血清と大動脈とでは一致し，肝 では異なつていることである.コレステロール投 与前には，血清と大動脈は，それぞれ異なつた脂 酸構成を維持していたのであるのに、 コレステロ
ールの投与でこのような類似の変化が血清と大動 脈の間にみられるのは, 恐らく，血清の脂酸構成 の変化が直接に大動脈に影響したもの上みること ができる．ところが，正常には血清と大動脈とは 異なつた脂酸構成をむつているのであるから，動 脈壁には生理的にmetabolic barrierの存在を推 測できる。

4）エラスターゼの抗動脈硬化作用の機序

エラスターセ゚の $\mathrm{E}_{1}$ 成分がAMP S の代謝に関与 し)，人体に拈いても。エラスタービの活性は脺 臓において年令とともに減じているといわれる また，血中のエラスターゼ阻止物質も硬化患者に 高值をみる という。こ机らの観点からエラスタ 一ゼが動脈壁の代謝に関与しているといわれてい る.わたくしの実験においても，エラスターゼ投 与時, 血中脂質の低下の少ないのに比べてアテロ 一ムの形成阻止が大きく, 分画脂質脂酸構成で大 動脈に特徽があり(図 $\left.\mathrm{B}_{2}\right)$ ，回復実験での動脈の脂 質代謝の改善に遅延があるなどによつて，エラス ターゼの壁代謝関与が考えられる。

その作用点にかんしては， $\mathrm{E}_{1} か ゙ \mathrm{AM}$ P S の代謝 に関与していることの匢が, AMP Sとリポ蛋 白には親和性があるから ${ }^{16)}$ A A P S とリポ蛋白 の結合をエラスターゼが切り離す防ことによつて 脂質の壁への沈着を防ぐという，乙かし，硬化巣 の限局性なること，発生部位に規則性があること を考えると，AMP S は本来脂質と親和性 が低 く，親和性の高い( ${ }^{18)}$ エラスチンを保護していると 考觉るのが妥当であるら．この考光方に立てば, AMP S は防御反応のための物質であり，metabolic barrierのにない手である. 硬化巣にしばし ばみられるといら ${ }^{199}$ AMP S の増量は, 一種の生


ラス多ーゼはAMPSの恒常性を維持するために 動くものと考えられよう。

硬化栄の規則的な局在性にかえしては，Texon またはBurton ${ }^{15)} の$ 述べている血管局所のLocus Minoris Resistentiaeを考えるのが適当である.

5）アテローム硬化成立機序の一般化した推論 
内膜に生理的にmetabolic barrierが存在すると 考えるならば，硬化の成立はこの機能の低下に起 因し，実験的アテローム硬化の場合には脂質の負 荷がきわめて大であるので，相対的に機能不全に 陥つたと考えることができる。

他方，自然発生のアテローム硬化症に䗆いて は, 高脂血症が存在せずとも起こつているので20), たとえばニラスターゼ等の内因珄の因子が絶体 的に欠乏して，ぞのためにmetabolic barrierが 機能低下したと考えることができる，無論，血 管壁への外因的な有害作用は 2 次的に metabolic barrierを破壊しえよらが，これは本論文の主題 を離れる。

\section{V. 結 論 \\ エラスターゼ (一つの内因性物質) の抗動脈硬} 化作用を示し，その作用機序を考察する.

1）コレステロール投与と同時に膵蔵性エラス ターゼを雄性家鬼に非経口的に投与するとアテロ 一ムの形成が阻止され，血清，大動脈，肝の総脂 質および分画脂質の脂酸構成が改善され，大動脈 と肝の脂質 ( $\mathrm{CH} ， \mathrm{~T} \mathrm{G}$ ) が減ずる.

既成のアテローム（実験的アテローム硬化）に 対してはェラスターゼの 1 カ月投与ではアテロー ムは回復しない，脂質の改善执よび脂酸構成の回 復は血清および肝では幾分認められるが，大動脈 および腹壁脂肪組織においては軽微である。

2）エラスターゼは脂質代謝よりる，動脈壁の
代謝に関連している事串を認めた。

健常家鬼およびュレステロール投与家鬼の，血 清, 大動脈, 肝の総脂質および分画脂質 (CE， $\mathrm{T} \mathrm{G}, \mathrm{PL}$ ）の脂酸構成の分析から, 大動脈壁に 生理的にmetabolic barrierの存在することが推測 された. そこでェラスターゼの作用は， metabolic barrierの保護にあると推定した。

\section{文献}

1) Anitschkow, N.: Beitr. Path. Anat., $56: 375$, 1913. -2) Schrade, W.: Klin. Wschr., 38 :


53, 1967. - 4) Butturini, U. et al.: Klin. Wschr., 40( 9 ) : 472, 1962. -5) Baló, J. et al.: Nature, $164: 491,1949$. -6) Hall, D.A.: Biochem. J., 70:5, 1958. -7) Aschoff, L.: Virchows Archiv für Path. Anat., 235 : 152,1921. 8) Bredt, H.: Atherosclerosis, 2nd Ed. ed. by F.G. Schettler and G.S. Boyd, Elsevier, Amsterdam(1969). -9) Duff, G.L.: Archiv. Path., $20: 81,1935 .-10)$ Zilversmit, D.B. et al.: Circulation, $33: 7,1966$. -11) Zemplenyi, T.: J. Atheroscler. Res., $7: 725,1967 .-12)$ Lindner, J.: Atherosclerosis (Schettler and Boyd), 1969. -13) Baló, J.: Excerpta Med. Sect., 20 (2) : 279, 1959. -14) Lansing, A.I.: J. Gerontl., 9 : 362, 1954. -15) Burton: Amer. J. Physiol., $164: 319,1951$. -16) 村上他 : 最新 医学, $18: 783,1963 .-17)$ Hall, D.A.: Arch. Biochem. Biophys., $67: 366$, 1957. -18) Labe1la, F.S.: Nature, $180: 1360,1957 .-19)$ Lindner, J.: Atherolerosis, (Schettler and Boyd) -20) Kannel, W.B. et al.: Ann. of Internal Med., 61 (51) : 888,1964. 